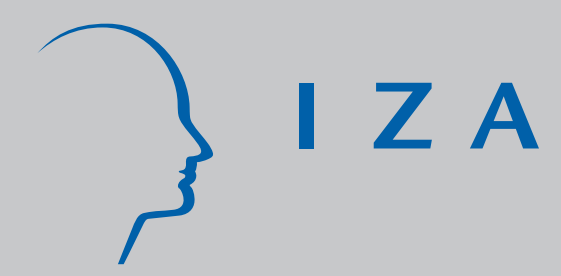

IZA DP No. 474

Unions, Works Councils and Plant Closings in Germany

J ohn T. Addison

Lutz Bellmann

Arnd Kölling

April 2002 


\title{
Unions, Works Councils and Plant Closings in Germany
}

\author{
John T. Addison \\ Moore School of Business, University of South Carolina, and IZA, Bonn \\ Lutz Bellmann \\ Institute for Employment Research (IAB), Nuremberg and IZA, Bonn \\ Arnd Kölling \\ Institute for Employment Research (IAB), Nuremberg
}

\author{
Discussion Paper No. 474 \\ April 2002
}

\author{
IZA \\ P.O. Box 7240 \\ D-53072 Bonn \\ Germany \\ Tel.: +49-228-3894-0 \\ Fax: +49-228-3894-210 \\ Email: iza@iza.org
}

This Discussion Paper is issued within the framework of IZA's research area Welfare State and Labor Markets. Any opinions expressed here are those of the author(s) and not those of the institute. Research disseminated by IZA may include views on policy, but the institute itself takes no institutional policy positions.

The Institute for the Study of Labor (IZA) in Bonn is a local and virtual international research center and a place of communication between science, politics and business. IZA is an independent, nonprofit limited liability company (Gesellschaft mit beschränkter Haftung) supported by the Deutsche Post AG. The center is associated with the University of Bonn and offers a stimulating research environment through its research networks, research support, and visitors and doctoral programs. IZA engages in (i) original and internationally competitive research in all fields of labor economics, (ii) development of policy concepts, and (iii) dissemination of research results and concepts to the interested public. The current research program deals with (1) mobility and flexibility of labor, (2) internationalization of labor markets, (3) welfare state and labor markets, (4) labor markets in transition countries, (5) the future of labor, (6) evaluation of labor market policies and projects and (7) general labor economics.

IZA Discussion Papers often represent preliminary work and are circulated to encourage discussion. Citation of such a paper should account for its provisional character. A revised version may be available on the IZA website (www.iza.org) or directly from the author. 
IZA Discussion Paper No. 474

April 2002

\begin{abstract}
Unions, Works Councils and Plant Closings in Germany

This paper present paper provides the first results for Germany on the impact of works councils and collective agreements on plant closings, using data from the IAB establishment panel. We find evidence of a robust positive association between works council presence and plant closures. The strictures of collective agreements do not seemingly affect closings. By the same token, and contrary to some recent findings on other aspects of establishment performance, the presence of a collective agreement does not attenuate the impact of local workplace representation on closings. Our analysis does nothing to encourage a sanguine view of recent legislation in Germany that facilitates the formation of works councils and strengthens their codetermination powers.
\end{abstract}

JEL Classification: J51, J53, J58, J65

Keywords: rent seeking, workplace representation, industry/regional collective bargaining, codetermination, plant closings

John T. Addison

Department of Economics

Moore School of Business

University of South Carolina

Columbia, SC 29208

USA

Tel.: +1-803-777-4608

Fax: +1-803-777-6876

Email: ecceaddi@darla.badm.sc.edu 


\section{Introduction}

Analysis of the effect of unions on workplace closure has long lagged investigation of their impact on such outcome measures as labor productivity, financial performance, and investment in physical

capital. This deficit is unfortunate for a number of reasons. Thus, for example, if the sample of union firms investigated is made up of survivors then a failure to observe adverse effects of unions on these standard performance indicators may be a chimera. And negative union effects on financial performance, where observed, may simply reflect the capture of economic rents or rent seeking that does not impair the joint surplus (perhaps even increasing it over some range). In both senses, absent information on plant closings our understanding of what it is that unions do is partial and may be said to lack corroboration. Again, analysis of union effects on firm survival may assist our understanding of other empirical regularities and in particular the contemporary decline in union density.

The focus of the present empirical inquiry is the impact of worker representation in Germany on plant closings. The system of collective bargaining that country differs markedly from Anglo-Saxon practice. In the German case, establishment bargaining is typically not the norm. Worker representation at the workplace occurs through the agency of the works council, which is formally independent of unions and enjoined not to engage in collective bargaining. However, as is well known, the bargaining power conveyed by workplace codetermination may of course result in higher wages and fringes at plant level while obviously influencing production. Collective bargaining proper is typically conducted at industry or regional level. ${ }^{1}$ In the present paper, therefore, in speaking of union effects we shall be looking at collective bargaining outside the establishment. The effects of workplace representation are measured by works council presence (or otherwise). Use of collective bargaining and workplace dummies not only captures the essence of the dual system of industrial relations in Germany but also addresses the notion that any exertion of rent seeking by the works council may be circumscribed by collective bargaining, ensuring that workplace representation focuses on production rather than distribution issues. Here the argument is that, absent collective agreements, distributional quarrels at establishment level can reduce the joint surplus and impair the 
survival of the plant (see Freeman and Lazear, 1995). The latter argument may appear recherché to some, but other pieces of research are not inconsistent with it. For example, some recent British research has suggested that adverse union effects on plant closings in post-Thatcher Britain may be indicative of union weakness rather than strength (see Bryson, 2001), while it has long been argued in U.S. research - though nowhere convincingly demonstrated - that the effects of, say, participation require a strong union backdrop to bear fruit (see, for example, the essays in Blinder, 1990).

So there are some common industrial relations themes leading us to expect a differentiated pattern of results from workplace and extra-workplace representation on outcomes and thence potentially on failure rates. The contemporary interest in this German inquiry is of course the very recent revision of the Works Constitution Act, which defines the rules setting up works councils and their competence. This new legislation facilitates the formation of works councils while increasing their powers. Our study covers an interval prior to passage of the new Betriebsverfassungsgesetz, but it has a bearing on legislation that was at least in part justified on efficiency grounds.

The plan of the paper is as follows. We first rehearse some theoretical conjectures on the likely nature of the association between worker representation and plant closings. We then briefly review the results of a sparse and thus far exclusively Anglo-Saxon empirical literature on unions and plant closings. This literature largely motivates the choice of variables used in this study, albeit with some 'local' adaptation to reflect German circumstances. There follows a discussion of our unique data set - the IAB establishment panel. Our empirical results are next presented. An interpretive section concludes.

\section{Conjectures on Worker Representation and Plant Closings}

There are a number of grounds for expecting worker representation to influence the probability of workplace closure. The Anglo-Saxon literature has broadly focused on union bargaining and collective voice. The bargaining approach is often associated with on-the-demand curve models, wherein unions seek to increase the wage but leave employment to the discretion of the employer. A large number of British and U.S. studies have indicated that the wage premium comes at the expense of profitability (see, inter al., 
Becker and Olson, 1992; Hirsch, 1991; Menezes-Filho, 1997). Ceteris paribus, the higher wage paid by union firms in a competitive product market ultimately threatens survivability. The mechanism is reduced profitability which reduces investment by limiting the self-financing of physical and intangible capital (assuming less than perfect capital markets) and by deterring firm investment in long-lived capital because of the quasi-rents available to capture. Empirical studies have confirmed that unions have negative effects on both profitability and investment (see Hirsch, 1991; Bronars and Deere, 1993). But as we shall see in section III, there is little direct evidence to link the union premium to closure rates, and in the British case the further suggestion that by the decade of the 1990s the union mark-up had largely disappeared (Bryson, 2002).

Much research effort has been devoted to explaining why higher wages may not translate into higher failure rates. Abstracting from productivity issues for the moment, it has been conventional to argue that the union premium comes out of above-normal profits, implying distributional rather than welfare consequences. This argument has received some support from efficient bargaining models, with contract curve (rather than demand curve) solutions that permit wages to be higher and employment at least no lower than under competition. In neither case, however, are these arguments particularly compelling. The former seems largely unsubstantiated empirically (Hirsch, 1991), while the latter ignores dynamic considerations and in particular the impact on investment in physical and intangible capital. That being said, it is by no means clear theoretically why investment need necessarily be lower: in a repeated game setting efficient self-enforcing contracts may result provided that the firm is sufficiently patient, even with sunk capital. In other words, even unions with no concern for the future can be deterred from cheating (Addison and Chilton, 1998). Moreover - and this bears on the finding that investment is reduced in unionized regimes - there is the possibility of opportunism on both sides of the table. In other words, union malfeasance does not necessarily underpin suboptimal investment where this is observed.

Altogether less formally, other observers have argued that unions have an interest in not pushing the employer to the brink and that, consistent with some excess over the opportunity wage, unions will seek to maintain the employment of their existing members. Thus, Freeman and Kleiner (1999, p. 512) assert that: "the rational union will 
not raise wages to the point where the firm is sufficiently unprofitable to go out of business ... and should grant wage concessions to keep the firm afloat as long as postconcession compensation exceeds the next best alternative for the workers." This assertion is adduced to receive support from studies indicating that unions give considerable weight to the employment goal (although the status of such studies is not independent of the efficacy of the underlying bargaining model such that the facts of union bargaining over employment do not speak for themselves).

This brings us to the second strand of the union literature, based on notions of collective voice (Freeman and Medoff, 1984). While it has been conventional to argue that union restrictive/protective practices and other limitations on the employer's right to manage (including delays in decision-making) impair firm survivability no less than the payment of supra-competitive wages, more recent approaches have focused on the potentially higher productivity of union workplaces. The ideas are by now familiar and need only briefly be noted. Union voice by aggregating over worker preferences can overcome certain public goods aspects of the workplace and allow the employer to select a more efficient mix of pay and working conditions. Further, by substituting for the exit mechanism, union voice can facilitate long-term employment relationships, cutting down on quits and encouraging investments in firm-specific capital. Again, unions can improve information exchange, encouraging employees to divulge private information beneficial to the production process. Under-provision of such valuable information is posited in circumstances where employees do not have the ability to limit opportunistic behavior by management following its disclosure. For all these reasons, it has been argued that unionized workplaces can pay higher wages and still compete with their unorganized counterparts, movements up the labor demand curve being counterbalanced by rightward shifts in that function. Interestingly, it is sometimes further argued that the union may also function as an agent of the employer principal, not in the old-fashioned sense of taking the wage out of competition but rather by maintaining and policing the supply of worker effort.

To be sure, the collective voice argument is fairly open-ended (e.g. being dependent in large part on a favorable response by management) and is only proffered as a second face of unionism, coexisting with the monopoly face. Further, it abstracts from 
alternative nonunion representative mechanisms for engaging the workforce, issues of direct versus representative participation, alternative gain-sharing routes, and in general underplays the importance of the reputation mechanism in regular markets. That said, it raises the possibility that productivity effects can blunt the plant closing implications of the union wage premium and may have especial relevance to the German case where worker representation at the workplace occurs via the works council - and where the external collective agreement may fulfill an agency role for the employer principal.

Turning therefore to the specific German context, we briefly review some findings on the impact of the works council before examining purpose-built models of that institution that also incorporate collective bargaining proper. As we have intimated, there are no studies of works council impact on plant closings. Rather, there is a body of evidence pertaining to works council effects on labor productivity, labor turnover, financial performance, investment, and innovation. While uncovering little direct evidence of rent-seeking behavior, the conclusion of the early literature was frankly pessimistic. That is to say, there is almost no indication of any favorable effect of this form of workplace representation on the particular performance indicator and some evidence of negative effects (see, inter al., Addison, Kraft and Wagner, 1993; Addison and Wagner, 1997; FitzRoy and Kraft, 1985, 1987; Kraft, 1986).

All such studies are based on small samples of firms that are examined in cross section, both of which aspects raise important problems of statistical inference. But there is also some more recent evidence, based on the Hannover Firm Panel, ${ }^{2}$ that does at least have a basis in large smples of firms and which points to a more differentiated pattern of results. One important finding is that different outcomes are detected by establishment size or by collective bargaining arrangement. Thus, there is a clear suggestion that unfavorable effects on labor productivity and profitability (and the payment of higher wages) may be largely confined to smaller plants with 100 or fewer employees (see, inter al., Addison, Siebert, Wagner, and Wei 2000; Addison, Schnabel, and Wagner, 2001), or to establishments that are not covered by a collective bargaining agreement (Hübler and Jirjahn, 2001).

We focus on the bargaining model of Hübler and Jirjahn (2001) because it provides a more direct context and helps inform out test procedure. The authors argue 
that where a works council is embedded in an external collective bargaining framework specifically, where the establishment is also covered by a collective bargaining agreement at industry/regional level - this will serve to dissipate distributional conflict at the workplace and at the same time enhance any pro-productive effect of the works council (on which more below). Central to the argument is the idea that the works council's bargaining power and its ability to hinder decision making is reduced in covered establishments. In principle, employers do not welcome councils but will anticipate that their power will be circumscribed if the establishment is covered by a collective agreement - though there are also costs to being a member of an employer's association. Similarly, workers know that the wage will be higher if there is a works council by virtue of the bargaining power conveyed by codetermination (but see Addison, Schnabel, and Wagner, 2001), albeit less so where there is a collective agreement. They also know that there are costs to them in setting up a works council (coordination and communication costs) and a certain sacrifice in utility from working conditions that require more effort. Both collective bargaining coverage and works councils are thus viewed as endogenous. The three-stage game envisaged by Hübler and Jirjahn admits of four outcomes: works council regimes with and without collective agreements and works council free situations with and without collective agreements according to the parameters of the model (namely, the cost of entering a collective agreement/forming a works council, the reference level of maximum worker effort, technology, and the scope of the works council to disrupt production.) The basic predictions of the model are twofold: (a) wages will be higher in firms with works councils; and (b) productivity and profitability may be higher or lower with works council presence but each is more likely to be positive where the firm is covered by a collective agreement. In implementing the model, using pooled data from the first and third waves of the Hannover Firm Panel and a double selection methodology, the authors find support for each prediction.

These are interesting results and in conformity with the Freeman-Lazear model of works councils, which argues that for the potential benefits of worker participation to be realized some mechanism has to be available for separating distribution from production issues if the potential voice benefits of works councils are to be realized. Simply mandating works councils is not enough because the corollary of employers offering too 
little employee involvement in regular markets (falling well short of that implied by the rights of works councils) is workers exploiting their increased involvement (via rent seeking). Accordingly, some limit has to be placed on the exertion of workplace bargaining power if a subopimal quantity of employee involvement in regular markets is not to be transformed into an excessive quantity under legislation promoting participation. Freeman and Lazear imply that the German legislation (to include the peace obligation), embedded as it is within a dual relations system, comes close to fitting the bill because of the partial uncoupling of the factors that determine the size of the surplus from those that determine its distribution. The Hübler-Jirjahn paper really seeks to establish whether the practicalities of the German mandate fit the idealized portrayal of it by Freeman and Lazear, as indeed do the other more recent German studies by questioning whether firms of different sizes might be differentially impacted.

The burden of the above is that, in investigating plant closings in the German case, we should pay regard to the relationship between collective bargaining coverage and works council presence. We have also to examine the independent impact of collective agreements, which may impair the survivability of marginal firms through the imposition of a common wage. Unlike Hübler and Jirjahn, will not seek to model the potential joint determination of works council status and collective agreement coverage given that works council status is practically a datum across time, but we will pay attention to the endogeneity of collective bargaining coverage given the nontrivial number of cases of firms leaving (and joining) collective agreements. ${ }^{3}$

\section{Extant Research on Plant Closings}

As was noted earlier, there is remarkably little evidence as to union impact on plant closings. Table 1 summarizes the extant research for Britain and the United States. The evidence is mixed both between and within the two countries. For Britain, studies based on the 1984 Workplace Industrial Relations Survey reveal scant evidence of any association between unionism and plant closings, irrespective of the union measure (see rows 1 and 2 of the table). Of no small interest is the finding that more powerful unions, as proxied by the magnitude of the wage premium or presence of the closed shop, have no discernible incremental effect on closings. Admittedly, the less aggregative U.S. 
evidence (see row 6) provides evidence of a statistically significant positive association between union density and plant closings. But union density has to be around 60 percent before this effect dominates the negative effect of union presence on closings; a degree of workplace organization that is approximately twice the sample mean.

(Table 1 near here)

The plot thickens when we come to consider the more recent British evidence. Broadly speaking, the sign of the coefficient estimate on the union variable is positive and statistically significant in studies using the 1990 Workplace Industrial Relations Survey. But this broad result hides as much as it reveals. Although reporting a material and robust positive association between either of two measures of unionism - recognition for collective bargaining purposes and union coverage - Addison, Heywood, and Wei (2001) find that this holds only for establishments that are part of larger (i.e. multiestablishment) undertakings. For single-plant entities (here firms), the direction of the association is reversed. (All studies support the more general result that single independent plants are less likely to close than their counterparts that are part of multiestablishment undertakings). The authors interpret the former result as consistent with a decline in union bargaining power in the wake of a decade of anti-union legislation, either by emboldening employers in multi-plant enterprises to close unionized establishments, or by weakening union influence over employment in such settings (see Machin, 1993). The single plant result, on the other hand, is rationalized in terms of (differential) union concessions in conjunction with rents.

While not contesting these findings, the recent study by Bryson (2001) offers a very different interpretation of the positive association between plant closings and unionism. Rather it is now union weakness - accentuated by the legislation - that is said to explain the sea change in union effect detected in the more recent workplace survey. Bryson reports that where unions are strong the coefficient estimate for unionism is no longer statistically significant. Stronger unions are identified by the closed shop and a combination of high density, bargaining coverage and on-site representatives, inter al. The weak union result is taken to be consistent with such unions being an ineffective voice for workers - and an inefficient agent for management - and conversely for strong unions. Without wishing to pursue the analogy too far, elements of the latter argument are 
echoed in German research on works councils, if not plant closings per se. We have seen that Hübler and Jirjahn (2001) report that negative works council effects on establishment financial performance and labor productivity are less likely to be negative where workplace representation accompanied by a collective agreement. But our earlier remarks have also indicated that works councils might also contribute to plant closings for reasons other than rent seeking; for example, by limiting management's freedom to recast the organization into a form that can adapt to change. (Interestingly, while necessarily downplaying rent seeking at local level in the very different industrial relations system in Britain and emphasizing the ineffective voice/weakened agency function of weak unions, Bryson nonetheless reports that bargaining over physical working conditions raised the likelihood of closure.)

\section{Data}

Our data are taken from four waves (1996-2000) of the Establishment Panel of the Institute for Employment Research of the Federal Labor Service (Institut für Arbeitsmarkt- und Berufsforschung der Bundsanstalt fur Arbeit). The basis for the panel is the employment statistics register of the Federal Employment Service, conducted within the framework of the 1973 revisions to the social insurance system. Each year, all employers are required, under sanction, to report levels of and changes in the number of their employees who are subject to the compulsory social security scheme. The register covers all dependent employment in the private and public sector, and accounts for almost 80 percent of total employment in western Germany. ${ }^{4}$ The survey unit of the register is the establishment or local production unit, rather than the legal and commercial entity of the company.

For its part, the establishment panel draws a stratified random sample of units from the register, the selection probabilities depending on the employment frequency of the respective stratum. The strata comprise some 16 industries and 10 establishment size intervals covering all sectors and employment levels. The overall and size-specific response rates exceed 60 percent and, for repeatedly-interviewed establishments, more than 80 percent (Kölling, 2000). 
The first wave of the establishment panel in 1993 contained data on 4,265 establishments. Since 1993 the panel has been augmented regularly to reflect establishment mortality, other exits, and newly-founded units. And in 1996 a panel was initiated for eastern Germany with an initial sample of 4,313 establishments. Currently, the overall number of establishments in the sample approximates 14,000, with the addition of eastern Germany and other regional samples.

The panel is designed to meet the needs of the Federal Labour Service, so that its focus is again on employment-related matters - although its scope is wider than the parent register. Much of the information in the panel concerns worker characteristics and qualifications, as well as levels of and changes in establishment employment. There is also information on the training and further training of employees, working time, and overtime. Additionally, information on certain establishment policies, business developments, and investment is similarly collected on an annual basis. Other information is collected biennially or triennially. Examples include works council status (first asked in 1996 and thence every other year), organizational changes, and use of public employment subsidies. Finally, each year the panel also addresses a specific theme; in 2000, for example, that theme was shortages of qualified manpower.

One clear advantage of the establishment panel is that, unlike its British counterpart (the Workplace Industrial/Employee Relations Survey), it is possible to track plant closings on an annual basis - rather than over an extended interval - and typically link this information to more contemporaneous economic and workplace data. ${ }^{5}$ It will be recalled that the panel component of the British data is used only to identify plants that closed six or eight years subsequent to date at which data on the presumed determinants of failures are available (1984 and 1990, respectively).

\section{(Table 2 near here)}

Two principal restrictions are placed on the data, other than the focus on western Germany. First, reflecting the fact that works councils are authorized (but not automatic) in all establishments with 5 or more employees, we excluded all plants in the sample with fewer than this number of employees. Second, as is conventional, we excluded those establishments that do not report business turnover. This restriction removed not only the nonprofit sector but also establishments in banking and insurance that fail so to report. As 
noted earlier, our sample period begins in 1996 because this is the first point in the life of the panel that a works council question was asked. It ends in 2000 with the most recent data available. Over the interval in questions, net of these restrictions, our full sample comprises some 3,693 establishments. Of these, 243 or 6.6 percent closed their doors between 1996 and 2000.

Descriptive statistics for the principal variables used in this inquiry are presented in Table 2. The dependent variable is a dummy variable that takes the value of one if the establishment closed in a particular year, zero otherwise. As can be seen from the table, the annual closure rate is just 2.6 per percent on average. The explanatory variables are with the exception of the two key industrial relations arguments - works council presence and application of an industry/regional collective agreement - familiar from the extant literature. (They are measured at the year in the year preceding the closure event.) Establishment size, status as a single independent establishment, and age have been found either individually or severally to be negatively associated with closure rates in the past. Of these variables, establishment age is a duration dependence measure. Worker characteristics that might manifest themselves in higher closure probabilities are low skill levels and the degree of utilization of atypical workers (namely, part-timers and those on fixed-term employment contracts). Skill levels are indirectly proxied here by the proportions of female workers and manual workers and directly by the share of qualified employees, defined as the proportion of employees possessing at least an apprenticeship qualification. The role of atypical work is admittedly less clear-cut because greater use of part-timers and fixed-term contracts may not simply be indicative of hard times but also pick up employment flexibility in response to exogenous shocks and hence survivability. But as a more direct measure of hard times we also include a measure of layoffs, defined as the number of compulsory redundancies relative to establishment employment. For its part, technology should be expected to influence closure probabilities in a beneficial manner. Our proxy for technology is a dummy variable set equal to one if the manager respondent claims that the establishment uses state-of-the-art technology, zero otherwise. (We also experimented with an additional technology argument, indicating whether or not the establishment reported investments in information and computer technology. Its impact was always negative but always reported with less precision than our preferred 
measure. $)^{6}$ The sole measure of product market competition available in the panel is exposure to foreign trade, and here it takes the form of a dummy variable assuming the value of unity if more than 50 percent of establishment turnover is generated through foreign sales. Finally, we use two 'external' variables, namely, the unemployment rate in the region (326 counties) of location of the establishment, and the establishment's onedigit and two-digit industry affiliation (respectively, 15 and 40 industry dummies).

\section{Findings}

German and other research on worker representation suggests that we should examine the effects of works councils on plants closings in close association with collective bargaining arrangements. Moreover, we should look for further differences in the impact of the works council by establishment status (single- versus multiple-establishment entities) and by establishment size (small versus larger plants). Tables 3 through 6 present results across these gradients.

\section{(Table 3 near here)}

Results for our base estimating equation are given in Table 3, using pooled data for 1996-2000. We eschew using fixed effects estimation because here is not sufficient variation in plant closings over time with a maximum of four observations per establishment. But, in recognition of the fact that individual firm observations are not independent, we provide 'clustered' standard errors throughout that allow for firm-specific error term variances. The first two columns of the table pertain to specifications that include the most aggregative industry controls. Beginning with the more parsimonious representation, it can be seen that the works council 'effect' is both positive and well determined. The coefficient estimate for collective bargaining coverage is opposite in sign but only marginally significant. Furthermore, when interacted with works council presence there is no suggestion that collective bargaining helps mitigate the seemingly adverse effect of local workplace representation. Consistent with previous research, however, the coefficient estimates for establishment size, establishment age, and single establishment status are negative and well determined. However, at this level of aggregation, there is no indication that the skill structure of the workforce, as proxied by the proportions of female and manual employees, influences establishment dissolutions. 
Adding in additional workforce composition variables together with technology, competition, and local labor market covariates, produces little change on the column 1 results, although the positive coefficient estimate for the share of female employees now becomes marginally statistically significant while the effect of collective bargaining coverage is estimated with less precision than before. Of the new variables, three are statistically significant at conventional levels. Thus, greater layoff experience and adverse local labor market conditions area associated with higher closures, and there is some modest indication that more advanced technology might help deflect closings. Interestingly, as can be seen from the last two columns of the table almost no change is occasioned when the (15) aggregative industry controls are replaced with 40 industry dummies.

(Table 4 near here)

These results suggest that the probability of plant closure is strongly elevated in the presence of works councils. In Table 4 we examine whether this general result also obtains when we distinguish between establishments that are independent firms and those that are part of multiestablishment enterprises. At first blush, the evidence seems to support British findings. That is to say, the coefficient estimate for works councils is highly statistically significant for single independent establishments, but not for establishments that are part of larger undertakings. However, as can be seen from the third column of the table, the difference in works council effect between the two types of establishment is not statistically significant. Again, there is no noticeable effect of collective bargaining in each sample, either alone or in interaction with works council presence. As far as the other variables are concerned, there are few sign reversals and only in the case of layoffs is there is any strong indication that that the positive effect of the variable differs between the samples. Greater layoffs are evidently a better signal of future plant closings in multi-establishment plants for reasons that might reflect a longer planning period.

\section{(Table 5 near here)}

Somewhat more pronounced differences are encountered when we distinguish between establishments of different size. Two employment cutoffs are used in Table 5. The first three columns of the table refer to establishments with less than and more than 
100 employees. No interaction between works council and collective agreement coverage is attempted here because almost all of the larger firms with a collective agreement also have a works council. In each case the effect of works council presence on the probability of closure is positive and statistically significant. The effect is much better determined for smaller establishments, but as a practical matter the difference in effect by establishment size is not statistically significant. There is the suggestion that closings are lower in smaller plants where there is a works council but we can put it no stronger than that. When we ran a separate equation for the smaller firm sampl, now interacting coverage and works council presence, the coefficient estimate for the interaction term was negative but statistically insignificant. ${ }^{7}$ Major differences between the two sizes of firm are in practice to be found elsewhere. As expected, the negative effect of establishment age is stronger for smaller establishments. That the negative effect of being a single establishment firm is stronger for larger establishments is again not unexpected and most probably reflects the fact that most smaller plants are independent entities. ${ }^{9}$ Layoffs appear a much stronger signal of impending closure in larger plants.

Using a lower establishment size cutoff of 50 employees in the last three columns of Table 5 produces little further differentiation. The magnitude of the works council effect is greater and better determined for smaller establishments employing less than 50 employees than for larger plants, but as before the difference is not statistically significant. One new result is the seemingly much stronger role of technology (and possibly labor quality, as proxied by the share of manual workers) in averting layoffs in smaller firms, although the difference in point estimates as between establishments in the two size intervals narrowly fails to achieve statistical significance. Again, the evidence of negative duration dependence is stronger for larger plants, as is the positive effect on closings of prior layoff experience.

\section{(Table 6 near here)}

Finally, in Table 6 we simply run our probit equations for separate samples of covered and uncovered plants. Contrary to our previous results, there is now at least the suggestion that where a works council is embedded in a collective bargaining framework the negative effects of local workplace representation might be muted. Thus, the positive effect of works councils on the likelihood of closure appears smaller in covered than 
uncovered plants and the difference is marginally statistically significant. The general results that establishment age, size and single establishment status are associated with fewer closings still obtains across both samples (though the effect of establishment size is stronger in the case of covered establishments). Interestingly, there is also the suggestion that higher local unemployment raises closings more in covered workplaces, which might capture the effects of one-size-fits all rigidities of the wage contract during hard times. But for other variables - in particular atypical work and qualified manpower - there are differences between the samples that have no obvious explanation.

In Tables 3 through 5 we have not reported on the results of accounting for the nonrandom distribution of collective agreements. Although we have little faith in our identifying restrictions, suffice it to say that instrumenting coverage did not materially alter our findings as to the impact of collective bargaining coverage. That still leaves the puzzle of the material in Table 6. In response to the latter, we estimated a version of the model in last column of Table 3 in which the propensity to be covered by a collective agreement was substituted for observed collective bargaining status. This predicted value was interacted with all the right hand side variables of the equation. ${ }^{9}$ The fully stacked model again revealed material differences between covered and uncovered plants, but the difference in works council effect between the two regimes pointed to in Table 6 vanished. This result is fully consistent with our previous findings in Tables 3 through 5.

Thus, while the works council-collective bargaining coverage nexus is annoyingly vague, there are few overt signs after all to suggest that the positive effect of workplace representation on closings is attenuated in covered undertakings. The dominant effect of works councils in elevating closures remains the central conclusion of this empirical exercise.

\section{Interpretation}

Using data from the IAB establishment panel, we first uncovered strong evidence of a positive association between works council presence and plant closings. The probit duration model producing these results also yielded sensible estimates for the other covariates. Consonant with previous research for other countries, plant closings were negatively associated with establishment size, establishment age, and single independent 
establishment status. Similarly, more advanced technology was associated with a lower probability of plant closings, while higher local unemployment and a higher frequency of compulsory redundancies typically were associated higher closure rates. However, workforce composition variables yielded few empirical insights. Inconsistent with past German research was, at this level of aggregation, the absence of a statistically significant interaction effects for works councils and collective bargaining coverage.

The positive association between works council presence and plant closings also obtained when we distinguished (a) between single independent establishments and those plants that were part of larger undertakings, and (b) small and large enterprises. In each case, although the coefficient estimates for the works council dummy were better determined for independent and smaller establishments than for their multi-establishment and larger counterparts, the differences in effect were not statistically significant. As for the role of collective agreements, there was no obvious indication that belonging to an employers' association lessened the impact of the works council effect in the case of single versus multiple-establishment plants. Moreover, there was only the weakest suggestion of this potential effect for smaller plants.

Only when we estimated separate equations by collective bargaining coverage was there any suggestion that the works council effect might be attenuated in the presence of a collective agreement. But when we interacted estimated collective agreement coverage with all the other covariates in the closings probit equation there was no indication of a reduction in the works council effect. This finding does not exhaust the potential of the works council-coverage nexus in performance analysis but it does nothing to displace our central result that works council presence is associated with sharply higher closing probabilities. These heightened probabilities of closure are summarized in Table 7 for each of the specifications contained in Tables 3 through 6.

\section{(Table 7 near here)}

It is interesting that the sign of the collective agreement variable though negative is generally statistically insignificant. There is thus no suggestion that the strictures of a collective agreement actually lead to plant closings. However, as we have also indicated, there are a significant number of defections from employers' associations. If such defectors were in imminent financial danger, we might anticipate a negative and 
statistically significant coefficient estimate for the coverage variable, via a selection mechanism. In fact, only a small number of firms which leave collective agreements fail in the next period. Accordingly, it seems that leaving a collective agreement may be less impelled by financial exigencies than other reasons (such as desire to make permanent alterations to working hours; see Kölling and Lehmann, 2001). More narrowly, the small numbers involved militated against our meaningfully interacting defections with works council presence - although inspection of the cases in question revealed that nearly all subsequent failures had works councils, purging them from the data produced no change in the works council coefficient estimate. More generally of course, the nontrivial number of changes in membership of collective agreements (in both directions) provided a justification for our endogenizing coverage, even if the results nowhere materially altered our conclusions as to the association between works council presence and plants closings.

Subject to the usual caveats regarding causation, the seemingly strong economic impact of works councils on plant closings patently offers scant support for recent changes in the German law facilitating works council formation and strengthening their powers. On July 28, 2001, the Works Constitution Reform Act (BetrVerf-Reformgesetz) entered into law after heated public debate. The new law facilitates works council formation by simplifying the voting procedures (in smaller establishments) that have to be followed in setting up a works council. It further increases the authority of the entity in a number of ways. These include lowering the employment size thresholds used to determine the size of the works councils and the number of full-time councilors, strengthening the influence of the works council in matters of employment protection and training, widening the functions of the works council, and extending both its consent and codetermination rights (e.g. on teamwork and environmental protection issues). Framers of the new mandate justified the changes not only in terms of industrial democracy but also in terms of putative efficiency advantages (see Addison, Bellmann, Schnabel, and Wagner, 2002, p. 9). Unfortunately, this latter justification was merely asserted and had no basis in the extant German empirical research which, as we have seen, scarcely offers a passing grade to the institution per se (see section III). The new findings reported here only serve to cast further doubt on the efficacy of legislation, unless the intention was after all to increase the speed of adaptation to change by accelerating plant closures. 


\section{Endnotes}

1. That said, company bargaining is on the increase in Germany. On which, see Bellmann, Kohaut,and Schnabel (1999).

2. The Hannover Firm Panel is a four-wave panel containing data on manufacturing establishments in Lower Saxony with 5 or more workers. For an English-language description of the project and the survey questionnaire, see Brand, Carstensen, Gerlach, and Klodt (1996).

3. Over the sample period, 228 plants (6.1 percent of the sample) joined collective agreements and 303 (8.2 percent) plants left them. The corresponding values for installation and abolition of a works council were 43 (1.2 percent) and 47 (1.3 percent), respectively.

4. The remainder comprise some civil servants, and all unpaid family workers, the self employed and those whose earnings/hours are insufficient to qualify them for social security benefits

5. On the other hand, the panel does not contain information on financial disclosure, the role of the industrial relations climate, takeovers, and foreign ownership (other than for eastern Germany). Similarly, information on two other variables of possible interest employee financial participation and employee involvement mechanisms - is available only for the 1995 wave of the panel.

6. We also experimented with a capacity utilization measure - available from 1997 onward - in regressions estimated for three waves of the panel. The coefficient estimate for this variable was uniformly statistically insignificant.

7. Some 78.9 percent (76.1 percent) of plants with less than 50 (100) employees are single establishment firms, whereas only 48.2 percent (44.0 percent) of their counterparts with 50 (100) or more employees are independent entities.

8. Specifically, the coefficient estimate for the interaction term was $-0.082(0.179)$. For the separate sample of plants with fewer than 50 employees, this coefficient estimate was larger $-0.246(0.221)$ - but again statistically insignificant at conventional levels.

9. The probit regression for estimating the probability of coverage uses the following exogenous variables: firm size, proportion of females, proportion of qualified blue- and white-collar workers, proportion of part-timers, proportion of employees on fixed-term contracts, export share of turnover, and dummies for the legal form of the plant, industry affiliation, and regional structure. Some 8,470 observations were used for the regression. The Pseudo- $\mathrm{R}^{2}$ was 0.143 and the mean (s.d.) of the estimated propensity was 0.695 (0.193). 


\section{References}

Addison, John T., Lutz Bellmann, Claus Schnabel, and Joachim Wagner. 2002. "The Long Awaited Reform of the German Works Constitution Act." Unpublished paper, Department of Economics, University of South Carolina, January.

Addison, John T., and John Chilton. 1998. "Self-enforcing Union Contracts: Efficient Investment and Employment." Journal of Business 71 (July): 349-369.

Addison, John T., John Heywood, and Xiangdong Wei. 2001. "Unions and Plant Closings in Britain: New Evidence from the 1990/1998 WERS." Unpublished Paper, Department of Economics, University of South Carolina, May

Addison, John T., Kornelius Kraft, and Joachim Wagner. 1993. "German Works Councils and Firm Performance." In Employee Representation: Alternatives and Future Directions, ed. Bruce E. Kaufman and Morris M. Kleiner, pp. 305-336. Madison, WI: Industrial Relations Research Association.

Addison, John T., Claus Schnabel, and Joachim Wagner. 2001. "Works Councils in Germany: Their Effects on Establishment Performance." Oxford Economic Papers 53 (October): 659-694.

Addison, John T., W. Stanley Siebert, Joachim Wagner, and Xiangdong Wei. 2000. "Worker Participation and Firm Performance: Evidence from Germany and Britain." British Journal of Industrial Relations 38 (March): 7-48.

Addison, John T., and Joachim Wagner. 1997. "The Impact of German Works Councils on Profitability and Innovation: New Evidence from Micro Data." Jahrbücher für Nationalökonomie und Statistik 216 (1): 1-20.

Bellmann, Lutz, Susanne Kohaut, and Claus Schnabel. 1999. "Flächentarifverträge im Zeichen von Abwanderung und Widerspruch: Geltungsbereich, Einflußfaktoren und Öffnungstendenzen." In Panelanalysen zu Lohnstruktur, Qualifikation und Beschäftigungsdynamik, ed. Lutz Bellmann and Viktor Steiner, pp. 9-40. Nürnberg: Institut für Arbeitsmarkt- und Berufsforschung der Bundesanstalt für Arbeit.

Becker Brian E. and Craig A. Olson. 1992. "Unions and Firm Profits." Industrial Relations 31 (Fall): 395-415.

Blinder, Alan S. (ed.). 1990. Paying for Productivity - A Look at the Evidence. Washington, D.C.: The Brookings Institution.

Brand, Ruth, Vivian Carstensen, Knut Gerlach, and Thomas Klodt. 1996. "The Hannover Panel." Discussion Paper No. 2, University of Hannover, May. 
Bronars, Stephen G., and Donald R. Deere. 1993. "Unionization, Incomplete Contracting, and Capital Investment." Journal of Business 66 (January) 117-132.

Bryson, Alex. 2001. "Unions and Workplace Closure in Britain, 1990-1998." Unpublished Paper, Policies Studies Institute, October.

Bryson, Alex. 2002. "The Union Membership Wage Premium: An Analysis Using Propensity Score Matching." Unpublished Paper, Policies Studies Institute, January.

Dunne, Timothy, and David A. Macpherson. 1994. "Unionism and Gross Employment Flows." Southern Economic Journal 60 (January): 727-738.

FitzRoy, Felix, and Kornelius Kraft. 1985. "Unionization, Wages, and Efficiency: Theories and Evidence from the U.S. and West Gemany." Kyklos 38 (4): 537-554.

FitzRoy, Felix, and Kornelius Kraft . 1987. "Efficiency and Internal Organization: Works Councils in West German Firms." Economica 54 (November): 493-504.

FitzRoy, Felix, and Kornelius Kraft. 1990. "Innovation, Rent-Sharing and the Organization of Labor in the Federal Republic of Germany." Small Business Economics 2 (2): $95-103$

Freeman, Richard B., and Morris M. Kleiner. 1999. "Do Unions Make Enterprises Insolvent?" Industrial and Labor Relations Review 52 (July): 510-527.

Freeman, Richard B. and James L. Medoff. 1984. What Do Unions Do? New York: Basic Books.

Freeman, Richard B. and Lazear, Edward P. 1995. "An Economic Analysis of Works Councils." In Works Councils: Consultation, Representation, and Cooperation in Industrial Relations, ed. Joel Rogers and Wolfgang Streeck, pp. 27-50. Chicago, Ill.: University of Chicago Press.

Hirsch, Barry T. 1991. Labor Unions and the Economic Performance of Firms. Kalamazoo, MI: W.E. Upjohn Institute for Employment Research.

Hübler, Olaf and Uwe Jirjahn. 2001. "Works Councils and Collective Bargaining in Germany: The Impact on Productivity and Wages." Discussion Paper No. 322, Institute for the Study of Labor (IZA), July.

Kölling, Arnd. 2000. "The IAB Establishment Panel." Schmollers Jahrbuch, Zeitschrift für Wirtschafts- und Sozialwissenschaften 120 (2): 291 - 300.

Kölling, Arnd, and Karen Lehmann. 2001."Arbeitszeitregelungen und Tarifbindung." In Beschäftigungseffekte betrieblicher Arbeitzeitgestaltung, ed. Lutz Bellmann, Knut 
Gerlach, Olaf Hübler, and Wolfgang Meyer, pp. 105-133. Nürnberg: Institut für Arbeitsmarkt- und Berufsforschung der Bundesanstalt für Arbeit.

Kraft, Kornelius. 1985. "Exit and Voice in the Labor Market: An Empirical Study of Quits." Journal of Institutional and Theoretical Economics 142 (December): 697-715.

Machin, Stephen. 1995. "Plant Closures and Unionization in British Establishments." British Journal of Industrial Relations 33 (March) 55-68.

Manning, Alan. 1993. "Pre-Strike Ballots and Wage-Employment Bargaining." Oxford Economic Papers 45 (July): 422 - 429.

Menezes-Filho. 1997."Unions and Profitability over the 1980s: Some Empirical Evidence on Union-Firm Bargaining in the U.K." Economic Journal 107 (May): 651-670.

Stewart, Mark B. 1995. "Union Wage Differentials in an Era of Declining Unionization." Oxford Bulletin of Economics and Statistics 57 (May): 143-167.

White, Halbert. 1980. "A Heteroskedasticity-Consistent Covariance Matrix Estimator and a Direct Test for Heteroskedasticity." Econometrica 48 (May): 817-838. 
Table 1: International Evidence of Union Effects on Plant Closings

\begin{tabular}{|c|c|c|c|}
\hline Study & Dataset/Methodology & Union variable & Controls \\
\hline $\begin{array}{l}\text { Britain } \\
\text { 1. Machin (1995) }\end{array}$ & $\begin{array}{l}1984 \text { WIRS, using data on } \\
\text { plants that subsequently } \\
\text { closed from the WIRS 1984- } \\
90 \text { Panel. Probit model. }\end{array}$ & Union recognition. & $\begin{array}{l}\text { Log number of employees, proportion nonmanual } \\
\text { workers, single plant, manufacturing dummies, } \\
\text { below average financial performance, operating } \\
\text { well below capacity. }\end{array}$ \\
\hline 2. Stewart (1995) & As above. Probit model. & $\begin{array}{l}\text { Predicted mean union } \\
\text { wage differential. }\end{array}$ & $\begin{array}{l}\text { Log number of employees, proportion nonmanual } \\
\text { workers, operating well below capacity, } \\
\text { manufacturing dummy. }\end{array}$ \\
\hline $\begin{array}{l}\text { 3. Addison, Heywood, } \\
\text { and Wei (2001) }\end{array}$ & $\begin{array}{l}1990 \text { WIRS, using data on } \\
\text { plants that subsequently } \\
\text { closed from WERS 1990-98 } \\
\text { Panel. Probit model. }\end{array}$ & $\begin{array}{l}\text { Union recognition; union } \\
\text { coverage. }\end{array}$ & $\begin{array}{l}\text { Establishment size, establishment age, proportion } \\
\text { female, proportion manual, proportion } \\
\text { professional/technical, proportion short-term } \\
\text { contracts, wide range of employee-involvement } \\
\text { and participation mechanisms, industrial relations } \\
\text { climate, technology variables, flexibility at } \\
\text { workplace, change in ownership, market power, } \\
\text { layoff experience, export exposure, regional } \\
\text { unemployment rate, one-digit and more detailed } \\
\text { (three or four digit) industry controls. }\end{array}$ \\
\hline 4. Bryson (2001) & As above & $\begin{array}{l}\text { Union recognition; union } \\
\text { strength ( } 3 \text { measures); } \\
\text { union type; number of } \\
\text { unions; bargaining } \\
\text { arrangements (e.g. single } \\
\text { vs. joint bargaining); and } \\
\text { bargaining scope. Probit } \\
\text { model. }\end{array}$ & $\begin{array}{l}\text { Industry-level union density, log number of } \\
\text { employees, proportion non- manual, single plant, } \\
\text { (10) regional dummies, (18) two-digit industry } \\
\text { controls, degree of competition, use of flexible } \\
\text { contracts, financial performance better than } \\
\text { average, operating considerably below capacity, } \\
\text { increase in employment. }\end{array}$ \\
\hline
\end{tabular}

Findings

nion recognition effect

statistically insignificant both

overall and by type of union

(manual and nonmanual), and in the

presence or otherwise of the closed shop. Result robust to inclusion of one-digit industry dummies.

Union wage differential statistically insignificant throughout.

Robust positive and statistically significant association between union measures and probability of plant closure. But the result is driven by plants that are part of multiestablishment undertakings. For single-establishment firms, the union effect(s) is negative and generally statistically insignificant.

Union measure(s) positively associated with plant closure. But magnitude and significance of the effect is sensitive to form of measure. Statistically significant effects where union is weak, for manual worker unions, single unions, and where union bargains over physical working conditions. 
United States

5. Dunne and

Macpherson (1994)

1999)
Sectoral-level death rates derived from establishment employment data from the Census of Manufactures micro-data files for 1997 and 1982. Union data from May 1979 CPS. OLS regression model.

Main analysis is for a sample of firms/business lines from COMPUSTAT I and II files, 1983-90, linked to

independent union density data. Probit model.

[Supplementary analyses of displaced workers using CPS displaced worker surveys for 1994 and 1996, and of rates of plant closure following

NLRB certification elections and dispute cases from the files of the Federal Mediation and Conciliation Service (FMCS)].
Sectoratlevel union density.

Unionization dummy in conjunction with union density; categorical measures of union density.
Price-cost margin, 3 establishment size dummies, 20 two digit and 73 three-digit industry dummies.

Age of firm, log sales, extent of union wage concessions, one-digit industry dummies, two-

digit industry concentration ratios and bankruptcy rates, and three-digit industry import penetration rate.
Sign of union density effect on sectoral death rates varies according to detail of industry controls Coefficient estimate for union density variables is statistically insignificant throughout.

Coefficient estimate for the unionization dummy is negative and statistically significant while that for union density positive and statistically significant insolvencies are only higher in union regimes where density equal to or greater than $60 \%$, or twice unionization rate of sample. For categorical measures of union density, the union effect is only positive and statistically significant for 'high' union density (i.e. $60 \%$ or more). Separate analysis of CPS

data suggests that probability that a worker will be displaced by plant closure is not materially influenced by union affiliation, while FMCS data point to closure rates that approximate annual plant closure rates in Annual Survey of Manufactures data (taken to be indicative of the average rate of plant closure absent new unionization) 
Table 2: Descriptive Statistics and Definition of Variables

\begin{tabular}{|c|c|c|c|c|}
\hline Variable & Obs. & Mean & Std. dev. & Definition \\
\hline Closed & 9240 & 0.026 & & $\begin{array}{l}\text { dummy }=1 \text { if the establishment closed by the } \\
\text { following year }\end{array}$ \\
\hline Collective agreement & 9218 & 0.695 & & $\begin{array}{l}\text { dummy }=1 \text { if collective agreement at industry or } \\
\text { regional level applied }\end{array}$ \\
\hline Works council & 9173 & 0.558 & & dummy $=1$ if works council present \\
\hline Est. size & 9226 & 4.561 & 1.832 & log establishment size \\
\hline Est. age & 8966 & 26.646 & 13.761 & age of establishment in years \\
\hline Single est. firm & 9182 & 0.609 & & dummy $=1$ if single establishment firm \\
\hline Prop. female & 9189 & 0.329 & 0.270 & proportion of female workers \\
\hline Prop. manual & 9219 & 0.545 & 0.311 & $\begin{array}{l}\text { proportion of manual workers (excluding } \\
\text { trainees) }\end{array}$ \\
\hline Prop. qualified & 9221 & 0.644 & 0.285 & $\begin{array}{l}\text { proportion of employees with at least an } \\
\text { apprenticeship (excluding trainees) }\end{array}$ \\
\hline Prop. part-time & 9120 & 0.134 & 0.194 & $\begin{array}{l}\text { proportion of part-time workers (excluding } \\
\text { trainees) }\end{array}$ \\
\hline Prop. fixed-term & 9151 & 0.034 & 0.084 & $\begin{array}{l}\text { proportion of those on fixed-term contracts } \\
\text { (excluding trainees) }\end{array}$ \\
\hline Layoffs & 9147 & 0.015 & 0.050 & $\begin{array}{l}\text { compulsory redundancies as a proportion of } \\
\text { employment (excluding trainees) }\end{array}$ \\
\hline Use of technology & 9205 & 0.232 & & dummy $=1$ if newest technology is used \\
\hline Export & 8801 & 0.112 & & $\begin{array}{l}\text { dummy }=1 \text { if exports contribute more than } 50 \\
\text { percent of plant turnover }\end{array}$ \\
\hline Unemployment & 8492 & 10.197 & 2.989 & $\begin{array}{l}\text { regional unemployment rates ( } 326 \text { counties in } \\
\text { western Germany) }\end{array}$ \\
\hline
\end{tabular}

Source: IAB Establishment Panel, 1996 - 2000, 
Table 3: Probit Estimates of the Effects of Works Councils and Collective Agreement Coverage on Establishment Closings, Pooled Regressions 1996-2000

\begin{tabular}{|c|c|c|c|c|}
\hline Variable & Parsimonious & Full & Parsimonious & Full \\
\hline \multirow[t]{2}{*}{ Constant } & $-0.703^{\star \star \star}$ & $-1.328^{\star \star \star}$ & $-0.667^{* \star}$ & $-1.274^{\star \star \star}$ \\
\hline & $(2.602)$ & (3.682) & $(2.479)$ & (3.529) \\
\hline \multirow[t]{2}{*}{ Collective Agreement } & $-0.148^{*}$ & -0.129 & $-0.165^{\star}$ & -0.144 \\
\hline & $\begin{array}{l}(1.667) \\
0.347^{* \star \star}\end{array}$ & $\begin{array}{l}(1.343) \\
0.316^{* *}\end{array}$ & $\begin{array}{l}(1.849) \\
0.343^{* * *}\end{array}$ & $\begin{array}{l}(1.481) \\
0.326^{\star *}\end{array}$ \\
\hline Works council & $(3.158)$ & $(2.489)$ & $(3.097)$ & $(2.539)$ \\
\hline Collective & -0.048 & -0.049 & -0.040 & -0.052 \\
\hline $\begin{array}{l}\text { agreement } \bullet \text { Works } \\
\text { council }\end{array}$ & $(0.387)$ & $(0.356)$ & $(0.317)$ & $(0.376)$ \\
\hline Est. size & $\begin{array}{l}-0.177^{* * *} \\
(6.638)\end{array}$ & $\begin{array}{l}-0.184^{* * *} \\
(6.064)\end{array}$ & $\begin{array}{l}-0.183^{* * *} \\
(6.880)\end{array}$ & $\begin{array}{l}-0.188^{\star * *} \\
(6.236)\end{array}$ \\
\hline Est. age & $\begin{array}{l}-0.008^{* * *} \\
(3.610)\end{array}$ & $\begin{array}{l}-0.007^{\star * \star} \\
(3.227)\end{array}$ & $\begin{array}{l}-0.008^{* * *} \\
(3.581)\end{array}$ & $\begin{array}{l}-0.008^{\star * \star} \\
(3.316)\end{array}$ \\
\hline Single est. firm & $\begin{array}{l}-0.247^{* * *} \\
(3.659)\end{array}$ & $\begin{array}{l}-0.285^{\star * *} \\
(3.917)\end{array}$ & $\begin{array}{l}-0.246^{* * *} \\
(3.622)\end{array}$ & $\begin{array}{l}-0.285^{\star * *} \\
(3.891)\end{array}$ \\
\hline Prop. female & $\begin{array}{c}0.200 \\
(1.463)\end{array}$ & $\begin{array}{l}0.341^{* *} \\
(1.977)\end{array}$ & $\begin{array}{c}0.202 \\
(1.374)\end{array}$ & $\begin{array}{c}0.349^{*} \\
(1.898)\end{array}$ \\
\hline Prop. manual & $\begin{array}{l}-0.028 \\
(0.255)\end{array}$ & $\begin{array}{c}0.079 \\
(0.596)\end{array}$ & $\begin{array}{l}-0.045 \\
(0.400)\end{array}$ & $\begin{array}{c}0.055 \\
(0.398)\end{array}$ \\
\hline Prop. qualified & & $\begin{array}{c}0.153 \\
(1.202)\end{array}$ & & $\begin{array}{c}0.133 \\
(1.021)\end{array}$ \\
\hline Prop. part-time & & $\begin{array}{c}0.024 \\
(0.112)\end{array}$ & & $\begin{array}{l}-0.021 \\
(0.099)\end{array}$ \\
\hline Prop. fixed-term & & $\begin{array}{c}0.353 \\
(0.963)\end{array}$ & & $\begin{array}{c}0.368 \\
(1.012)\end{array}$ \\
\hline Layoffs & & $\begin{array}{l}1.374^{* * *} \\
(3.095)\end{array}$ & & $\begin{array}{l}1.290^{\star \star \star} \\
(2.913)\end{array}$ \\
\hline Use of technology & & $\begin{array}{l}-0.146^{*} \\
(1.806)\end{array}$ & & $\begin{array}{l}-0.149^{*} \\
(1.820)\end{array}$ \\
\hline Export & & $\begin{array}{l}-0.028 \\
(0.236)\end{array}$ & & $\begin{array}{l}-0.020 \\
(0.171)\end{array}$ \\
\hline Unem ployment & & $\begin{array}{l}0.028^{\star * *} \\
(2.743)\end{array}$ & & $\begin{array}{l}0.028^{\star \star \star} \\
(2.764)\end{array}$ \\
\hline 15 industry dummies & Included & Included & & \\
\hline 40 industry Dummies & & & Included & Included \\
\hline 3 yearly dummies & Included & Included & Included & Included \\
\hline $\mathrm{N}$ & 8711 & 7486 & 8520 & 7283 \\
\hline Pseudo $\mathrm{R}^{2}$ & 0.055 & 0.071 & 0.064 & 0.079 \\
\hline
\end{tabular}

Note: Heteroscedastic-consistent |t|-values in parentheses, White's (1980) method. ${ }^{* * *}$, ${ }^{* *}$ and ${ }^{*}$ denote significance at the $.01 . .05$ and .10 levels, respectively. The first (last) two columns of the table present results using 15 (40) industry dummies. 
Table 4: Probit Estimates of the Effects of Works Councils and Collective Agreement Coverage on Establishment Closings by Establishment Type, Pooled Regressions 1996-2000

\begin{tabular}{|c|c|c|c|}
\hline Variable & Single establishments & Multi-establishments & (difference) \\
\hline \multirow[t]{2}{*}{ Constant } & $-1.566^{\star \star \star}$ & -0.900 & \\
\hline & $(3.508)$ & $(1.294)$ & \\
\hline \multirow{2}{*}{ Collective agreement } & -0.180 & -0.041 & -0.139 \\
\hline & $(1.574)$ & $(0.196)$ & $(0.576)$ \\
\hline \multirow[t]{2}{*}{ Works Council } & $0.492^{\star * *}$ & 0.358 & 0.134 \\
\hline & $(2.738)$ & $(1.626)$ & $(0.446)$ \\
\hline \multirow[t]{2}{*}{ Collective agreement $\bullet$ Works council } & -0.044 & -0.158 & 0.114 \\
\hline & $(0.225)$ & $(0.634)$ & $(0.374)$ \\
\hline \multirow[t]{2}{*}{ Est. size } & $-0.261^{* * *}$ & $-0.163^{* * *}$ & -0.098 \\
\hline & $(5.830)$ & $(4.056)$ & $(1.567)$ \\
\hline \multirow[t]{2}{*}{ Est. age } & $-0.010^{* * *}$ & $-0.007^{*}$ & -0.003 \\
\hline & (3.162) & $(1.928)$ & $(0.660)$ \\
\hline \multirow[t]{2}{*}{ Prop. female } & $0.535^{\star *}$ & 0.121 & 0.414 \\
\hline & $(2.257)$ & $(0.397)$ & $(1.092)$ \\
\hline \multirow[t]{2}{*}{ Prop. manual } & 0.103 & 0.006 & 0.097 \\
\hline & $(0.514)$ & $(0.028)$ & $(0.302)$ \\
\hline Prop. qualified & $\begin{array}{c}0.257 \\
(1.412)\end{array}$ & $\begin{array}{c}0.038 \\
(0.191)\end{array}$ & $\begin{array}{c}0.219 \\
(0.782)\end{array}$ \\
\hline \multirow[t]{2}{*}{ Prop. part-time } & 0.074 & 0.024 & 0.050 \\
\hline & $(0.284)$ & $(0.061)$ & $(0.090)$ \\
\hline Prop. fixed-term & $\begin{array}{c}0.641^{*} \\
(1.657)\end{array}$ & $\begin{array}{l}-0.265 \\
(0.298)\end{array}$ & $\begin{array}{c}0.906 \\
(0.946)\end{array}$ \\
\hline Layoffs & 0.785 & $3.491^{* * *}$ & $-2.294^{* *}$ \\
\hline \multirow{2}{*}{ Use of technology } & $-0.264^{* *}$ & $\begin{array}{l}(3.3 / 4) \\
-0.002\end{array}$ & $\begin{array}{l}(2.204) \\
-0.266\end{array}$ \\
\hline & $(2.367)$ & $(0.018)$ & $(1.595)$ \\
\hline Export & $\begin{array}{l}-0.053 \\
(0.267)\end{array}$ & $\begin{array}{l}-0.071 \\
(0.466)\end{array}$ & $\begin{array}{c}0.018 \\
(0.019)\end{array}$ \\
\hline Unemployment & $\begin{array}{l}0.033^{* *} \\
(2.481)\end{array}$ & $\begin{array}{c}0.020 \\
(1.301)\end{array}$ & $\begin{array}{c}0.013 \\
(0.687)\end{array}$ \\
\hline 40 industry dummies & Included & Included & Included \\
\hline 3 yearly dummies & Included & Included & Included \\
\hline $\mathrm{N}$ & 4242 & 2716 & \\
\hline$\chi^{2}$ (df.) & & & $58.00^{\star *}(37)$ \\
\hline Pseudo $\mathrm{R}^{2}$ & 0.109 & 0.081 & \\
\hline
\end{tabular}

Note: Heteroscedastic-consistent |t|-values in parentheses, White's (1980) method. ${ }^{* * *}$, ${ }^{* *}$ and ${ }^{*}$ denote significance at the .01 .05 and .10 levels, respectively. Single establishments refer to independent plants; multi-establishments are establishments that are part of multi establishment undertakings. 
Table 5: Probit Estimates of the Effects of Works Councils and Collective Agreement Coverage on Establishment Closings by Establishment Size, Pooled Regressions 1996-2000

\begin{tabular}{|c|c|c|c|c|c|c|}
\hline \multirow[b]{2}{*}{ Variable } & \multicolumn{6}{|c|}{ Type of Establishment } \\
\hline & $>=100 \mathrm{empl}$. & $<100$ empl. & (diff.) & $>=50 \mathrm{empl}$ & $<50$ empl. & (diff.) \\
\hline Constant & $\begin{array}{l}-1.943^{\star \star \star} \\
(3.035)\end{array}$ & $\begin{array}{l}-1.581^{\star \star \star} \\
(5.523)\end{array}$ & & $\begin{array}{l}-1.163^{\star \star} \\
(2.509)\end{array}$ & $\begin{array}{l}-1.633^{\star \star \star} \\
(5.068)\end{array}$ & \\
\hline Collective agreement & $\begin{array}{l}-0.080 \\
(0.579)\end{array}$ & $\begin{array}{l}-0.201^{* *} \\
(2.321)\end{array}$ & $\begin{array}{c}0.121 \\
(0.818)\end{array}$ & $\begin{array}{l}-0.119 \\
(1.079)\end{array}$ & $\begin{array}{l}-0.210^{* *} \\
(2.181)\end{array}$ & $\begin{array}{c}0.091 \\
(0.669)\end{array}$ \\
\hline Works council & $\begin{array}{c}0.473^{*} \\
(1.744)\end{array}$ & $\begin{array}{l}0.355^{\star * *} \\
(3.390)\end{array}$ & $\begin{array}{c}0.118 \\
(0.386)\end{array}$ & $\begin{array}{c}0.285^{*} \\
(1.836)\end{array}$ & $\begin{array}{l}0.380^{* * *} \\
(3.000)\end{array}$ & $\begin{array}{l}-0.095 \\
(0.427)\end{array}$ \\
\hline Est. size & $-0.188^{* *}$ & $-0.145^{\star * *}$ & -0.039 & $-0.216^{\star * *}$ & $-0.180^{\star *}$ & -0.036 \\
\hline Est. age & $\begin{array}{l}(2.542) \\
-0.002\end{array}$ & $\begin{array}{l}(2.606) \\
-0.011^{\star * *}\end{array}$ & $\begin{array}{c}(0.445) \\
0.009\end{array}$ & $\begin{array}{l}(3.877) \\
-0.002\end{array}$ & $\begin{array}{l}(2.457) \\
-0.014^{\star * *}\end{array}$ & $\begin{array}{c}(0.421) \\
0.012^{* *}\end{array}$ \\
\hline & $(0.390)$ & $(3.822)$ & $(1.509)$ & $(0.524)$ & $(4.315)$ & $(2.169)$ \\
\hline Single est. firm & $\begin{array}{l}-0.576^{\star * *} \\
(4.219)\end{array}$ & $\begin{array}{l}-0.158 \\
(1.577)\end{array}$ & $\begin{array}{l}-0.418^{* *} \\
(2.351)\end{array}$ & $\begin{array}{l}-0.452^{\star * *} \\
(4.246)\end{array}$ & $\begin{array}{l}-0.150 \\
(1.229)\end{array}$ & $\begin{array}{l}-0.302^{*} \\
(1.855)\end{array}$ \\
\hline Prop. female & $\begin{array}{c}0.350 \\
(0.889)\end{array}$ & $\begin{array}{c}0.362^{*} \\
(1.731)\end{array}$ & $\begin{array}{l}-0.012 \\
(0.038)\end{array}$ & $\begin{array}{c}0.394 \\
(1.238)\end{array}$ & $\begin{array}{c}0.256 \\
(1.103)\end{array}$ & $\begin{array}{c}0.138 \\
(0.382)\end{array}$ \\
\hline Prop. m anual & $\begin{array}{l}-0.121 \\
(0.385)\end{array}$ & $\begin{array}{c}0.096 \\
(0.605)\end{array}$ & $\begin{array}{l}-0.217 \\
(0.588)\end{array}$ & $\begin{array}{l}-0.255 \\
(1.042)\end{array}$ & $\begin{array}{c}0.266 \\
(1.534)\end{array}$ & $\begin{array}{l}-0.521^{*} \\
(1.659)\end{array}$ \\
\hline Prop. qualified & $\begin{array}{c}0.247 \\
(0.958)\end{array}$ & $\begin{array}{c}0.113 \\
(0.720)\end{array}$ & $\begin{array}{c}0.134 \\
(0.357)\end{array}$ & $\begin{array}{c}0.003 \\
(0.015)\end{array}$ & $\begin{array}{c}0.246 \\
(1.366)\end{array}$ & $\begin{array}{l}-0.243 \\
(0.917)\end{array}$ \\
\hline Prop. part-time & $\begin{array}{c}0.428 \\
(0.987)\end{array}$ & $\begin{array}{l}-0.209 \\
(0.859)\end{array}$ & $\begin{array}{c}0.637 \\
(1.217)\end{array}$ & $\begin{array}{c}0.118 \\
(0.315)\end{array}$ & $\begin{array}{l}-0.162 \\
(0.594)\end{array}$ & $\begin{array}{c}0.280 \\
(0.516)\end{array}$ \\
\hline Prop. fixed-term & $\begin{array}{c}0.831 \\
(0.920)\end{array}$ & $\begin{array}{c}0.284 \\
(0.781)\end{array}$ & $\begin{array}{c}0.547 \\
(0.491)\end{array}$ & $\begin{array}{c}0.570 \\
(0.720)\end{array}$ & $\begin{array}{c}0.397 \\
(1.014)\end{array}$ & $\begin{array}{c}0.173 \\
(0.111)\end{array}$ \\
\hline Layoffs & $\begin{array}{l}4.583^{\star * *} \\
(2.951)\end{array}$ & $\begin{array}{l}1.028^{* *} \\
(2.142)\end{array}$ & $\begin{array}{l}3.555^{\star *} \\
(2.077)\end{array}$ & $\begin{array}{l}3.142^{\star \star \star} \\
(3.513)\end{array}$ & $\begin{array}{c}0.587 \\
(1.059)\end{array}$ & $\begin{array}{l}2.555^{\star *} \\
(2.525)\end{array}$ \\
\hline Use of technology & $\begin{array}{l}-0.018 \\
(0.127)\end{array}$ & $\begin{array}{l}-0.199^{* *} \\
(2.044)\end{array}$ & $\begin{array}{c}0.181 \\
(1.002)\end{array}$ & $\begin{array}{l}-0.017 \\
(0.146)\end{array}$ & $\begin{array}{l}-0.273^{\star *} \\
(2.438)\end{array}$ & $\begin{array}{c}0.256 \\
(1.586)\end{array}$ \\
\hline Export & $\begin{array}{l}-0.064 \\
(0.419)\end{array}$ & $\begin{array}{l}-0.015 \\
(0.074)\end{array}$ & $\begin{array}{l}-0.049 \\
(0.127)\end{array}$ & $\begin{array}{l}-0.055 \\
(0.399)\end{array}$ & $\begin{array}{c}0.106 \\
(0.429)\end{array}$ & $\begin{array}{l}-0.161 \\
(0.550)\end{array}$ \\
\hline Unemployment & $\begin{array}{c}0.021 \\
(1.193)\end{array}$ & $\begin{array}{l}0.027^{* *} \\
(2.077)\end{array}$ & $\begin{array}{l}-0.006 \\
(0.002)\end{array}$ & $\begin{array}{c}0.023 \\
(1.431)\end{array}$ & $\begin{array}{r}0.026^{*} \\
(1.870)\end{array}$ & $\begin{array}{c}0.003 \\
(0.153)\end{array}$ \\
\hline 40 industry dummies & Included & Included & Included & Included & Included & Included \\
\hline 3 yearly dummies & Included & Included & Included & Included & Included & Included \\
\hline $\mathrm{N}$ & 3254 & 3876 & & 4050 & 3047 & \\
\hline$\chi^{2}$ (df.) & & & $53.26^{* *}(36)$ & & & $59.94^{* * *}(36)$ \\
\hline Pseudo $\mathrm{R}^{2}$ & 0.093 & 0.076 & & 0.096 & 0.103 & \\
\hline
\end{tabular}

Note: Heteroscedastic-consistent |t|-values in parentheses, White's (1980) method. ${ }^{* * *},{ }^{* *}$ and ${ }^{*}$ denote significance at the .01 .05 and .10 levels, respectively. 
Table 6: Probit Estimates of the Effects of Works Councils and Collective Agreement Coverage on Establishment Closings by Collective Agreement Coverage, Pooled Regressions 1996-2000

\begin{tabular}{|c|c|c|c|}
\hline \multirow[b]{2}{*}{ Variable } & \multicolumn{3}{|c|}{ Collective Bargaining Status } \\
\hline & Covered & Uncovered & (diff.) \\
\hline Constant & $\begin{array}{l}-1.517^{\star \star \star} \\
(4.923)\end{array}$ & $\begin{array}{l}-1.543^{\star \star \star} \\
(4.358)\end{array}$ & \\
\hline Works council & $\begin{array}{c}0.191^{*} \\
(1.647)\end{array}$ & $\begin{array}{l}0.557^{* * *} \\
(3.474)\end{array}$ & $\begin{array}{l}-0.366^{*} \\
(1.895)\end{array}$ \\
\hline Est. size & $\begin{array}{l}-0.164^{* * *} \\
(4.402)\end{array}$ & $\begin{array}{l}-0.283^{* * *} \\
(5.391)\end{array}$ & $\begin{array}{r}0.119^{*} \\
(1.845)\end{array}$ \\
\hline Est. age & $\begin{array}{l}-0.006^{\star} \\
(1.956)\end{array}$ & $\begin{array}{l}-0.013^{\star \star *} \\
(3.383)\end{array}$ & $\begin{array}{c}0.007 \\
(1.616)\end{array}$ \\
\hline Single est. firm & $\begin{array}{l}-0.293^{* * *} \\
(3.200)\end{array}$ & $\begin{array}{l}-0.291^{* *} \\
(2.196)\end{array}$ & $\begin{array}{l}-0.002 \\
(0.013)\end{array}$ \\
\hline Prop. female & $\begin{array}{c}0.167 \\
(0.670)\end{array}$ & $\begin{array}{l}0.641^{* *} \\
(2.254)\end{array}$ & $\begin{array}{l}-0.474 \\
(1.302)\end{array}$ \\
\hline Prop. manual & $\begin{array}{c}0.013 \\
(0.069)\end{array}$ & $\begin{array}{c}0.250 \\
(1.256)\end{array}$ & $\begin{array}{l}-0.237 \\
(0.912)\end{array}$ \\
\hline Prop. qualified & $\begin{array}{l}-0.096 \\
(0.564)\end{array}$ & $\begin{array}{l}0.562^{* * *} \\
(2.755)\end{array}$ & $\begin{array}{l}-0.658^{* *} \\
(2.498)\end{array}$ \\
\hline Prop. part-time & $\begin{array}{l}-0.013 \\
(0.046)\end{array}$ & $\begin{array}{c}0.038 \\
(0.112)\end{array}$ & $\begin{array}{l}-0.051 \\
(0.068)\end{array}$ \\
\hline Prop. fixed-term & $\begin{array}{l}-0.656 \\
(0.899)\end{array}$ & $\begin{array}{l}0.940^{* *} \\
(2.034)\end{array}$ & $\begin{array}{l}-1.596^{*} \\
(1.883)\end{array}$ \\
\hline Layoffs & $\begin{array}{l}1.417^{\star *} \\
(2.414)\end{array}$ & $\begin{array}{c}1.061 \\
(1.501)\end{array}$ & $\begin{array}{c}0.356 \\
(0.315)\end{array}$ \\
\hline Use of technology & $-0.231^{* *}$ & 0.008 & -0.239 \\
\hline Export & $\begin{array}{l}(2.036) \\
-0.142 \\
(0.992)\end{array}$ & $\begin{array}{c}(0.064) \\
0.200 \\
(0.962)\end{array}$ & $\begin{array}{l}(1.394) \\
-0.342 \\
(1.373)\end{array}$ \\
\hline $\begin{array}{l}\text { Unemployment } \\
40 \text { industry dummies }\end{array}$ & $\begin{array}{l}0.038^{* * *} \\
\text { (3.004) } \\
\text { Included }\end{array}$ & $\begin{array}{l}0.002 \\
(0.101)\end{array}$ & $\begin{array}{l}0.036 \\
(1.632) \\
\text { Included }\end{array}$ \\
\hline 40 industry dummies & $\begin{array}{l}\text { Included } \\
\text { Included }\end{array}$ & Included & Included \\
\hline $\begin{array}{l}3 \text { yearly dummies } \\
\mathrm{N}\end{array}$ & $\begin{array}{l}\text { Included } \\
5014\end{array}$ & 2033 & micluaed \\
\hline $\begin{array}{l}\chi^{2}(\mathrm{df} .) \\
\text { Pseudo } \mathrm{R}^{2}\end{array}$ & 0.076 & 0.131 & $70.14^{* * *}(35)$ \\
\hline
\end{tabular}

Note: Heteroscedastic-consistent |t|-values in parentheses, White's (1980) method. ${ }^{* \star *}$, ${ }^{*}$ and ${ }^{*}$ denote significance at the $.01 . .05$ and .10 levels, respectively. 
Table 7: Estimated Marginal Effects of Works Council Presence on the Probability of Establishment Closure

Marginal Effect

Specification Percentage point

Percentage

Table 3

Parsimonious (15 industry dummies)

1.8

65.2

Full (15 industry dummies)

1.5

56.8

Parsimonious (40 industry dummies)

62.2

Full (40 industry dummies)

1.7

56.5

Table 4

Single establishment

2.2

86.3

Multi-establishment plant

1.7

51.8

Table 5

Est. size greater 100 employees

0.8

50.0

Est. size less than 100 employees

2.7

74.8

Est. size greater 50 employees

0.8

37.3

Est. size less than 50 employees

3.0

78.9

Table 6

Covered establishment

0.8

32.5

Uncovered establishment

3.5

95.0

Note: Marginal effects are defined for a discrete change (from 0 to 1 ) in the works council variable. 


\section{IZA Discussion Papers}

No.

Author(s)

M. Biewen

459

460

B. R. Chiswick

Y. Liang Lee

P. W. Miller

M. Gurgand

D. N. Margolis

462

463

464

J. Ermisch

M. Francesconi

J. E. Askildsen

E. Bratberg

$\varnothing$. A. Nilsen

Y. Liang Lee

P. W. Miller

W. Schnedler

U. Sunde
A. Venturini
C. Villosio

J. Wagner

R. Lalive

J. C. van Ours

J. Zweimüller
A. Cigno
F. C. Rosati
L. Guarcello

71 B. R. Chiswick

Y. Liang Lee

P. W. Miller

$472 \quad$ R. Foellmi

J. Zweimüller

J. C. van Ours
J. T. Addison

L. Bellmann

A. Kölling
Title

Area

Date

The Covariance Structure of East and West

3

03/02

German Incomes and its Implications for the

Persistence of Poverty and Inequality

Family Matter: The Role of the Family in

2

03/02

Immigrants' Destination Language Acquisition

Welfare and Labor Earnings:

3

03/02

An Evaluation of the Financial Gains to Work

The Determinants of the Geographic

2

03/02

Concentration among Immigrants: Application to

Australia

Labor Supply Dynamics, Unemployment and

03/02

Human Capital Investments

The Hold-Down Problem and the Boundaries of the Firm: Lessons from a Hidden Action Model with Endogenous Outside Option

Intergenerational Social Mobility and Assortative Mating in Britain

Unemployment, Labour Force Composition and 1 Sickness Absence: A Panel Data Study

Are Immigrants Competing with Natives in the 1 Italian Labour Market? The Employment Effect

The Impact of Risk Aversion, Role Models, and the Regional Milieu on the Transition from Unemployment to Self-Employment: Empirical Evidence for Germany

The Effect of Benefit Sanctions on the Duration of Unemployment

04/02

Does Globalisation Increase Child Labour?

Immigrants' Language Skills and Visa Category

Structural Change and the Kaldor Facts of Economic Growth

A pint a day raises a man's pay; but smoking

5

04/02 blows that gain away

Unions, Works Councils and Plant Closings in

3

$04 / 02$ 